\title{
Physical activity at work and duodenal ulcer risk
}

\author{
B D Katschinski, R F A Logan, M Edmond, M J S Langman
}

\begin{abstract}
To determine whether the social class differences in duodenal ulcer frequency may be explained by differences in physical activity at work, the energy expenditure during work, smoking habits, and social class were compared in 76 recently diagnosed duodenal ulcer patients and in age and sex matched community controls. As anticipated, the relative risk of duodenal ulcer showed significant associations with smoking and social class. Social class and physical activity at work were associated with one another. After adjusting for age, sex, smoking, and social class, physically active work was still associated with duodenal ulcer, with relative risks for moderate and high activity compared with sedentary work being $1.3(0.6-3.0)$ and $3.6(1.3-7.8)$ respectively. Within each social class stratum, the relative risk of having a duodenal ulcer was greater in those with a high level of occupational activity than in those undertaking sedentary work.
\end{abstract}

Departments of

Therapeutics and Public

Health and

Epidemiology, University

of Nottingham,

Nottingham

B D Katschinski

R F A Logan

$M$ Edmond

M J S Langman

Correspondence to:

Dr R F A Logan, Department

of Public Health and

Epidemiology, University of

Nottingham, Medical School,

Queen's Medical Centre,

Queen's Medical Centre,
Nottingham NG7 2UH.

Accepted for publication

4 October 1990
In the United States and England and Wales occupation specific mortality from peptic ulcer shows a high mortality for both types of ulcer among manual workers and a low mortality among sedentary occupations, ${ }^{1}$ and workers employed in manual labour in West Germany have been reported to carry a twofold risk of developing duodenal ulcer. ${ }^{2}$ Sonnenberg has suggested that the decline in duodenal ulcer in Europe and the United States may be related to the decrease in human labour. ${ }^{2}$ The relation between energy expenditure during work and the risk of duodenal ulceration has not yet been examined in case control or cohort studies and we now do so by means of a case control study.

\section{Methods}

\section{CASE SERIES}

All patients aged 20 to 60 years who had a duodenal ulcer identified by endoscopy in the two major hospitals in Nottingham between 1 April 1985 and 31 March 1986 were considered for the study. Data on occupations were collected as part of a study of dietary factors in duodenal ulcer, the results of which have been published separately. ${ }^{3}$ To reduce the effect of dietary changes resulting from chronic symptoms, patients with episodic recurrences of symptoms in the last two years were excluded. Patients who had a medical disorder requiring dietary treatment, such as diabetes, or those with serious psychiatric illness were also excluded. Patients in whom a duodenal ulcer had been diagnosed by barium meal only were not considered. Table I gives details of the case series.

\section{CONTROL SUBJECTS}

Each patient was matched with two control subjects who lived in the same area of Nottingham as the case. Controls were identified from the records of 12 general practices which were chosen to reflect the range of neighbourhoods and living conditions experienced by the cases. Matched controls were selected by visiting general practitioners' surgeries and identifying from the surgery records the next two subjects of the same sex and age within five years who were listed alphabetically after the case's surname. Those with a history of peptic ulceration, diabetes, or life threatening or terminal disease were not considered. In the United Kingdom, $\mathbf{9 8 \%}$ of the population are registered with general practitioners.

\section{METHOD OF INQUIRY}

Cases and controls were asked to complete a postal questionnaire which included questions on demographic characteristics, marital status, present occupation, smoking habits, and a semiquantitative food frequency schedule. If the questionnaires had not been returned after six weeks, second and, if necessary, third questionnaires were sent six to eight weeks later.

\section{CLASSIFICATION OF OCCUPATION}

Each occupational activity was rated as low, moderate, or high according to the energy expended during work. These ratings were based on tables reporting the calorie expenditure according to workload for 100 different jobs in German company studies of work in $1969 .{ }^{4}$ The corresponding calorie expenditure for the three

$\begin{array}{lcc}\text { Occupational data not available } & 7 & 4 \\ \text { Unemployed } & 3 & 6 \\ \text { Retired } & 2 & 6 \\ \text { No answer } & 76 & 150 \\ \text { Subjects available for occupational } & 62(82) & 116(77) \\ \text { analysis } & 56(74) & 110(73) \\ \text { No of men } & \end{array}$

$\mathrm{RR}=$ relative risk; $\mathrm{CI}=$ confidence interval. 
TABLE II Occupational activity levels for cases and controls according to type of occupation

\begin{tabular}{|c|c|c|c|c|c|c|c|c|}
\hline & \multicolumn{2}{|c|}{ Sedentary } & & \multicolumn{2}{|c|}{ Moderate } & & \multicolumn{2}{|l|}{ High } \\
\hline & $\begin{array}{l}\text { Cases } \\
(n=10) \\
(\%)\end{array}$ & $\begin{array}{l}\text { Controls } \\
(n=38) \\
(\%)\end{array}$ & & $\begin{array}{l}\text { Cases } \\
(n=37) \\
(\%)\end{array}$ & $\begin{array}{l}\text { Controls } \\
(n=90) \\
(\%)\end{array}$ & & $\begin{array}{l}\text { Cases } \\
(n=29) \\
(\%)\end{array}$ & $\begin{array}{l}\text { Controls } \\
(n=22) \\
(\%)\end{array}$ \\
\hline $\begin{array}{l}\text { Personnel/labour officers } \\
\text { Bus/lorry drivers } \\
\text { Civil servants } \\
\text { Scientists } \\
\text { Accountants } \\
\text { Computer programmers } \\
\text { Bank officers } \\
\text { Knitters }\end{array}$ & $\begin{array}{l}2(3) \\
3(4) \\
4(5) \\
- \\
\overline{1}(1) \\
- \\
-\end{array}$ & $\begin{array}{l}11(7) \\
9(6) \\
6(4) \\
6(4) \\
2(1 \cdot 3) \\
2(1 \cdot 3) \\
1(0 \cdot 7) \\
1(0 \cdot 7)\end{array}$ & $\begin{array}{l}\text { Machinists } \\
\text { Engineers } \\
\text { Supervisors/foremen } \\
\text { Housewives } \\
\text { Salesmen } \\
\text { Teachers } \\
\text { Printers } \\
\text { Restaurant/bar managers } \\
\text { Sales representatives } \\
\text { Warehousemen } \\
\text { Sales clerks } \\
\text { Ambulancemen } \\
\text { Cleaners } \\
\text { Painters } \\
\text { Electronic wirers } \\
\text { Bakers } \\
\text { Assemblers } \\
\text { Physicians } \\
\text { Janitors }\end{array}$ & $\begin{array}{l}4(5) \\
1(1) \\
5(7) \\
1(1) \\
2(3) \\
1(1) \\
- \\
6(8) \\
3(4) \\
4(5) \\
1(1) \\
2(3) \\
2(3) \\
2(3) \\
2(3) \\
1(1) \\
- \\
- \\
-\end{array}$ & $\begin{array}{l}7(5) \\
16(11) \\
11(7) \\
9(6) \\
7(5) \\
6(4) \\
5(3) \\
4(3) \\
4(3) \\
4(3) \\
4(3) \\
4(3) \\
3(2) \\
2(1 \cdot 3) \\
1(0 \cdot 7) \\
- \\
1(0 \cdot 7) \\
1(0 \cdot 7) \\
1(0 \cdot 7)\end{array}$ & $\begin{array}{l}\text { Miners } \\
\text { Labourers } \\
\text { Heavy equipment mechanics } \\
\text { Gardeners/farmers } \\
\text { Sheet metal workers } \\
\text { Welders } \\
\text { Plumbers } \\
\text { Motor mechanics } \\
\text { Postmen }\end{array}$ & $\begin{array}{l}7(9) \\
6(8) \\
5(7) \\
3(4) \\
3(4) \\
2(3) \\
2(3) \\
1(1) \\
-\end{array}$ & $\begin{array}{l}4(3) \\
6(4) \\
6(4) \\
- \\
\overline{2}(1 \cdot 3) \\
1(0 \cdot 7) \\
2(1 \cdot 3) \\
1(0 \cdot 7)\end{array}$ \\
\hline
\end{tabular}

levels of activity was classified as below $600 \mathrm{kcal}$, 600 to $1200 \mathrm{kcal}$, and above $1200 \mathrm{kcal}$ per day. For each job a minimum and a maximum value of calorie expenditure were stated in the tables. In order to allow grouping, the mean value of calorie expenditure of a particular job was chosen as relevant for the grading of occupational activity.

Social class was based on the Registrar General's classification, with subjects being classified on the basis of current occupation. ${ }^{5}$

\section{DATA ANALYSIS}

Data were first analysed by stratifying on a single confounding variable, and the relative risk estimates obtained are the odds ratios calculated from the Mantel-Haenszel formulae. In order to control for the combined effect of several confounding variables, a multivariate analysis using conditional logistic regression for matched sets (programs from Dr J Esteve, IARC, Lyon) was also used to calculate relative risks with $95 \%$ confidence intervals. ${ }^{6}$ Variables included in the model were age, sex, smoking, and social class. The relative risk for sedentary work was arbitrarily defined as $1 \cdot 0$.

TABLE III Relative risk of duodenal ulcer by occupational activity levels and social class

\begin{tabular}{|c|c|c|c|}
\hline \multirow[b]{2}{*}{ Social class } & \multicolumn{3}{|c|}{ Occupational activity level } \\
\hline & $\begin{array}{l}\text { Sedentary } \\
(N)\end{array}$ & $\begin{array}{l}\text { Moderate } \\
(N)\end{array}$ & $\begin{array}{l}\text { High } \\
(N)\end{array}$ \\
\hline \multicolumn{4}{|l|}{1 and 2} \\
\hline Cases & 2 & 11 & 1 \\
\hline Controls & 18 & 26 & 1 \\
\hline RR & $1 \cdot 0$ & $3 \cdot 8$ & $9 \cdot 0$ \\
\hline \multicolumn{4}{|l|}{3} \\
\hline Cases & 7 & 18 & 18 \\
\hline Controls & 19 & 49 & 15 \\
\hline $\mathrm{RR}$ & $1 \cdot 0$ & $1 \cdot 0$ & $3 \cdot 3$ \\
\hline \multicolumn{4}{|l|}{4 and 5} \\
\hline Cases & 1 & 8 & 10 \\
\hline Controls & 1 & 15 & 6 \\
\hline RR & $1 \cdot 0$ & 0.53 & $1 \cdot 7$ \\
\hline \multicolumn{4}{|l|}{ All social classes } \\
\hline $\begin{array}{c}\text { Crude RR } \\
(95 \% \mathrm{CI})\end{array}$ & $\begin{array}{l}1 \cdot 0 \\
(0 \cdot 7-3 \cdot 5)\end{array}$ & $\begin{array}{l}1 \cdot 6 \\
(2 \cdot 1-12)\end{array}$ & $5 \cdot 0$ \\
\hline $\begin{array}{l}\text { RR adjusted for social } \\
\text { class only }\end{array}$ & $1 \cdot 0$ & $\begin{array}{l}1 \cdot 4 \\
(0 \cdot 7-3 \cdot 2)\end{array}$ & $\begin{array}{l}3 \cdot 3 \\
(1 \cdot 2-8 \cdot 5\end{array}$ \\
\hline $\begin{array}{l}\mathrm{RR}^{\star} \\
(95 \% \mathrm{CI})\end{array}$ & $1 \cdot 0$ & $\begin{array}{l}1 \cdot 3 \\
(0 \cdot 6-3 \cdot 0)\end{array}$ & $\begin{array}{l}3 \cdot 6 \\
(1 \cdot 3-7 \cdot 8\end{array}$ \\
\hline
\end{tabular}

^Based on logistic regression model including age, sex, smoking and social class. $\mathbf{R R}=$ relative risk; $\mathrm{CI}=$ confidence interval.

\section{Results}

A total of 104 cases and 208 controls were initially approached. For 11 cases and 29 controls no questionnaires were returned and for five cases and 13 controls the questionnaires were returned because of incorrect addresses. Eighty eight $(85 \%)$ of the cases and $166(80 \%)$ of the controls returned questionnaires, but for 12 cases and 16 controls the data on current occupation were inadequate for classification (Table I).

To assess potential confounding factors, the effect of known risk factors such as smoking and social class was examined (Table I). Moderately increased risks of duodenal ulcer were found in exsmokers and current smokers compared with those who had never smoked and for social classes 3, 4, and 5 compared with social classes 1 and 2.

Table II shows the occupations of the 76 cases and 150 controls stratified according to their activity levels. While $15 \%$ of the control population were found in the high activity group, the proportion of duodenal ulcer cases with a high occupational activity was $38 \%$.

Table III shows that relative risks increased in a stepwise manner as activity increased. In those with a moderate and high activity level, they were 1.6 and 5.0 respectively, the latter association being significant. After adjusting for social class, the relative risk for the intermediate and the high activity levels were slightly reduced, being 1.4 and 3.3 respectively. When each social class stratum was analysed individually the positive association with physical activity was less noticeable; when the social classes 3 and 4 , and 5 were considered individually the relative risk gradient generally persisted. After adjustment for occupational activity a significant association between social class and duodenal ulcer risk was no longer evident, the relative risk of those in social classes 4 and 5 in relation to classes 1 and 2 having a duodenal ulcer was $1 \cdot 5(0 \cdot 6-4 \cdot 0)$. Data were also stratified by smoking habit and relative risks for occupational activity levels were analysed (Table IV). No substantial change in relative risk was noted when high $v$ low activity was compared within non-smokers and smokers, the risks being 5.6 and 6.0 respectively.

The effect of occupational activity was also 
TABLE IV Relative risk of duodenal ulcer by occupational activity levels and smoking habits

\begin{tabular}{|c|c|c|c|}
\hline \multirow[b]{2}{*}{ Smoking habit } & \multicolumn{3}{|c|}{ Occupational activity level } \\
\hline & $\begin{array}{l}\text { Sedentary } \\
(N)\end{array}$ & $\begin{array}{l}\text { Moderate } \\
(N)\end{array}$ & $\begin{array}{l}\text { High } \\
(N)\end{array}$ \\
\hline \multicolumn{4}{|l|}{ Non-smokers: } \\
\hline Cases & 1 & 6 & 3 \\
\hline Controls & 13 & 23 & 7 \\
\hline \multirow{2}{*}{\multicolumn{4}{|c|}{ Ex-smokers: }} \\
\hline & & & \\
\hline Cases & 2 & 6 & 3 \\
\hline Controls & 3 & 17 & 3 \\
\hline $\mathbf{R} \mathbf{R}$ & 1.0 & 0.53 & 1.5 \\
\hline \multicolumn{4}{|l|}{ Smokers: } \\
\hline Cases & 7 & 25 & 23 \\
\hline Controls & 22 & 50 & 12 \\
\hline RR & $1 \cdot 0$ & 1.6 & 6.0 \\
\hline $\begin{array}{l}\text { RR adjusted for smoking } \\
(95 \% \mathrm{CI})\end{array}$ & $1 \cdot 0$ & $\begin{array}{l}1 \cdot 5 \\
(0 \cdot 7-3 \cdot 40)\end{array}$ & $\begin{array}{l}4 \cdot 8 \\
(2 \cdot 0-12)\end{array}$ \\
\hline
\end{tabular}

$\mathbf{R R}=$ relative risk $\mathbf{C I}=$ confidence intervals .

examined in relation to sex and age (Table V). The risk of duodenal ulcer increased progressively in both men and women according to the level of activity. The relative risks of having an ulcer were also significantly increased in both age strata.

\section{Discussion}

This study suggests that duodenal ulcer is associated with a high level of physical activity during work that seems to act independently of the effects of age, sex, and smoking. Acceptance of this observation depends on whether the study is considered valid in terms of its classification of occupations, avoidance of recall or information bias, suitability of cases and controls, and perhaps most importantly identification and adjustment for possible confounding factors.

The only data we collected on physical activity concerned current occupation, as the original purpose of the study was to examine diet and the analysis of physical activity was considered only after reading Sonnenberg's reports. ${ }^{127}$ We have no information about leisure time activity or the physical activity of the unemployed. Occupations were classified according to a recent German classification; a similar British classifica-

TABLE V Effect of sex and age on duodenal ulcer risk due to occupational activity

\begin{tabular}{|c|c|c|c|}
\hline & \multicolumn{3}{|c|}{ Occupational activity level } \\
\hline & $\begin{array}{l}\text { Sedentary } \\
(N)\end{array}$ & $\begin{array}{l}\text { Moderate } \\
(N)\end{array}$ & $\begin{array}{l}\text { High } \\
(N)\end{array}$ \\
\hline \multicolumn{4}{|l|}{ Men: } \\
\hline Cases & 7 & 28 & 27 \\
\hline Controls & 29 & 67 & 20 \\
\hline $\begin{array}{l}\text { RR } \\
(95 \% \mathrm{CI})\end{array}$ & $1 \cdot 0$ & $\begin{array}{l}1 \cdot 8 \\
(0 \cdot 7-4 \cdot 4)\end{array}$ & $\begin{array}{l}5 \cdot 6 \\
(2 \cdot 1-15)\end{array}$ \\
\hline \multicolumn{4}{|l|}{ Women: } \\
\hline Cases & 3 & 9 & 2 \\
\hline Controls & 9 & & \\
\hline $\begin{array}{l}\text { RR } \\
(95 \% \mathrm{CI})\end{array}$ & $1 \cdot 0$ & $\begin{array}{l}1 \cdot 2 \\
(0 \cdot 3-5 \cdot 4)\end{array}$ & $\begin{array}{l}3 \cdot 0 \\
(0 \cdot 3-30)\end{array}$ \\
\hline \multicolumn{4}{|c|}{ Age $<40$ years: } \\
\hline Cases & 1 & 7 & 12 \\
\hline Controls & 8 & & \\
\hline RR & $1 \cdot 0$ & $2 \cdot 2$ & $11 \cdot 1$ \\
\hline$(95 \% \mathrm{CI})$ & & $(0 \cdot 2-19)$ & $(2 \cdot 2-118)$ \\
\hline \multicolumn{4}{|c|}{ Age $>40$ years: } \\
\hline Cases & 9 & 30 & 17 \\
\hline Controls & 30 & 64 & 16 \\
\hline RR & $1 \cdot 0$ & 1.6 & 3.5 \\
\hline$(95 \% \mathrm{CI})$ & & $(0 \cdot 7-3 \cdot 7)$ & $(1 \cdot 3-9 \cdot 5)$ \\
\hline
\end{tabular}

$\mathbf{R R}=$ relative risk $; \mathrm{CI}=$ confidence intervals tion is still in preparation. Although this is not ideal and may have led to some misclassification, it is difficult to conceive how this could be a source of bias. Misclassification, which is a random effect, can be expected to underestimate the role of activity and so result in relative risk estimates biased towards unity. ${ }^{8}$

Recall bias as to current occupation seems unlikely to be important. Information on occupation was obtained in the same way for cases and controls and response rates were high. Compared with the cases, however, proportionately more of the controls who responded were from social classes 1 and 2 than from the lower social classes (Table III). This difference is presumably the result of a lower response rate from controls in social classes 4 and 5, although we cannot be sure as we have no information on the occupations of non-responders. The results in Table III have been stratified by social class to adjust for the confounding introduced by the greater proportion of controls from the higher social classes and show that the relation between occupational activity existed in each of the three broad social class strata.

Although the case series was derived from all patients with a newly diagnosed duodenal ulcer seen at endoscopy, from a defined geographic area over one year, patients referred to hospital represent only a small proportion of all ulcer patients. It seems unlikely that the amount of physical activity at work should directly influence hospital referral but the possibility cannot be excluded. As nearly half of the patients had had a past history of peptic ulceration there is also the possibility that occupational activity was influenced by disease severity. Patients with established ulcer disease might have gravitated towards less physically demanding work; ${ }^{9}{ }^{10}$ such a trend would tend to diminish rather than increase observed differences.

For these reasons we think the relative risk estimates presented here may underestimate the true strength of an association between physical activity and duodenal ulcer. Nonetheless, the increases in risk are quite substantial when compared with established risk factors such as smoking and social class. Though smoking and social class differences might have been expected to explain the observed association of ulcer with physical activity, it transpired that standardisation for both did not eliminate the physical activity gradient. Indeed our findings suggest that the social class gradient for duodenal ulcer may at least be partly accounted for by work being more physically active in social classes four and five. Alternatively physical activity could be a marker of some other exposure. Dietary factors are an obvious possibility but in our analysis of diet the addition of physical activity to the conditional logistic regression model resulted in no statistically significant advantage.

Our results agree with observations that in the German workforce manual workers more frequently develop peptic ulcers than sedentary workers.' These results are consistent with an analysis of occupational mortality for the United States and England and Wales which suggested increasing mortality with increasing energy expenditure during work.' Sonnenberg has also 
found that in Germany the rates for which disability pensions are granted to employees because of duodenal ulceration correlates significantly with the amount of occupational energy expenditure."

Contrary evidence comes from the occupational survey by Doll et al which showed the incidence of peptic ulcer to be similar in bus drivers and conductors and low in agricultural workers, ${ }^{9}$ while a recent Norwegian study showed a higher incidence of gastroduodenal ulcers in fishermen and of duodenal ulcers in transport workers than in the other occupational groups."

The pathophysiological mechanisms through which physical activity might promote duodenal ulceration are unclear. It is possible that mucosal blood flow is altered by physical work, thus producing vascular damage as has been shown for aspirin induced mucosal injury. It is also not known whether alterations in nutrient intake secondary to increased energy demands could promote a tendency to duodenal ulceration. This is a preliminary study which we hope will stimulate larger case control studies, and inter alia these should pay particular attention to total energy expenditure in patients with first episodes of proved duodenal ulceration.
BK was supported by Deutsche Forschungsgemeinschaft, grant number Ka 665/1-1

Abstract published in Gastroenterology 1988; 94: A218.

1 Sonnenberg A, Sonnenberg GS. Occupational mortality from gastric and duodenal ulcer. $\mathrm{Br}$ F Ind Med 1986; 43: 50-5.

2 Sonnenberg A, Haas J. Joint effect of occupation and nationality on the prevalence of peptic ulcer in German workers. Brf Ind Med 1986; 43: 490-3.

3 Katschinski BD, Logan RFA, Edmond M, Langman MJS Duodenal ulcer and refined carbohydrate intake - a casecontrol study assessing dietary fibre and refined sugar intake. Gut 1990; 31: 993-6.

4 Verband fur Arbeitsstudien. Tafeln fur den Kalorienumsat bei korperlicher Arbeit. Sonderheft der REFAbei korperlicher Arbeit.

5 Office of Population Censuses and Surveys. Classification of occupations. London: HMSO, 1980.

6 Breslow NE, Day NE. Statistical methods in cancer research. Vo I: The analysis of case-control studies. Lyon: Internationa Agency for Research on Cancer, 1980.

7 Sonnenberg A. Environmental factors in peptic ulcer disease in peptic ulcer disease. In: Rees WDW, ed. Proceedings of the Seventh BSG-SKF Workshop 1986. London: Smith Kline and French Laboratories, 1987.

8 Rothman K. Modern epidemiology. Boston: Little Brown Company, 1986

9 Doll R, Avery Jones F, Buckatzsch MM. Occupational factors in the aetiology of gastric and duodenal ulcers with an in the aetiology of gastric and duodenal ulcers with an estimate of their incidence in the general population. Medical Research Council

10 Susser M. Causes of peptic ulcer. F Chron Dis 1967; 20: 435 66.

11 Sonnenberg A, Sonnenberg GS. Occupational factors in disability pensions for gastric and duodenal ulcer. $\mathcal{F} O c c u p$ Med 1986; 28: 87-90.

12 Ostensen H, Burhol PG, Stormer J, Bonnevie D. The incidence of peptic ulcer disease related to occupation in the northern part of Norway. Scand F Gastroenterol 1985; 20: 79- 